Paterson, Holt Radium Institute, Wilmslow Road, Withington, Manchester; Mr. H. S. Souttar; Sir George Thomson, Imperial College of Science and Technology, London, S.W.7; Prof. B. W. Windeyer, Meyerstein Institute of Radiotherapy, Middle-

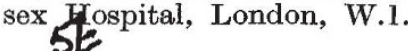

Research in Industry

UNDER the title "Research in Industry" the Department of Sclentific and Industrial Research and the Boald of Trade have issued a reprint of nineteen Mrifles published in the Board of Trade Jganal Wetween May 1947 and March 1948. This panpalet of 84 pages is published by H.M. Stationery Office and costs $1 s, 6 d$. The articles are written to illustrate factually the contention that the use of science in industry is essential for the survival of Great Britain. There are contributions by the directors or other officers of the research associations, indicating the part those associations are taking in the progress of the cotton, wool, iron and steel, rayon, pottery, linen, boot and shoe, paint, furniture, electrical and consumer-goods industries; and these articles are supported by others on electronics as an aid to production, the glass industry, the lace industry, the plastics industry, machine tool and small tool research for the engineering industry, the light-engineering industry, and industrial design research, and by a contribution from Sir Robert Watson-Watt on the industrial application of radar in peace-time. Sir Edward Appleton has written a general introduction on how science can help industry, in which he once again emphasizes the importance of securing the widest possible dissemination of knowledge of the results of research and its utilization in Great Britain. While the articles are admirable as an introduction, they are no substitute for the individual reports of the research boards, stations or research associations, still less of the Department of Scientific and Industrial Research as a whole, the pre-war annual report of which was an important document for knowledge of scientific and technical progress.

\section{Fundamental Education}

IN 1947 the United States National Commission for Unesco cons trated a Panel on Fundamental Education to cousider how the proposals set out in the Unesc forok, "Fundamental Education-Common Grdund for all Peoples", could be applied in the Un fed States. The panel meets under the chairman. shipl of Mr. John W. Studebaker, the Commissioner for Education, and is composed of specialists in many fields concerned with fundamental education who are broadly representative of various public and private agencies and associations throughout the country. Its first bulletin, called "Fundamental Education", has now been issued and provides important technical information both on the way in which the Unesco Secretariat may carry out the international project and also on the way the development of fundamental education in the United States may be encouraged. Copies of the bulletin may be obtained from the Superintendent of Documents, U.S. Government Printing Office, Washington.

New?

New Zealand Earthguakes during 1946

Accospriget the Dominion Observatory Bulletin, No $5-8$, Gere were recorded in New Zealand, during 194273 locally felt earthquakes. One of these, on
June 26, was felt with Modified Mercalli scale 7-8, while five others, on February 12, February 26, June 7, June 28 and September 14, were felt with scale 6 . The remainder had lesser intensities. The general distribution of earthquakes was such that most had epicentres north of the latitude of Christchurch with very few to the south of this line. There was a strong cluster of epicentres to the south-southwest of Arthur's Pass at the northern end of the Southern Alps, and the epicentre of the shock of June 26 was in this region. Another cluster lay in the Tasman Sea towards Cook Strait, while further epicentres tended to lie towards the median line of North Island between Wanganui and the Bay of Plenty, and others in the Pacific Ocean to the northeast of New Zealand. The second greatest shock, that on February 12 (scale $6+$ ), had its epicentre at a point to the south-east of Wanganui at the southern end of North Island.

Palæozoic Arachnida $6 / 2$ arachnologist, hat urmshed an account of the Palæozoic Arachnia in the Transactions of the Connecticut Academ of Arts and Sciences, vol. 37, 1949 (New Havqn.Conn., pp. 257, 7.70 dollars). This is particularly interesting in Great Britain, since it is very largely based on the rich collection of material in Aritish Museum (Natural History). It is not simply a description of species, although 169 species are dealt with, but rather a review of their structure, classification and relationships. In order to carry out this work adequately, full cognizance is taken of the considerable advances made in recent years in our knowledge of the comparative anatomy and development of living forms. The description of the structure of both fossil and living Arachnida in general, the adequate definitions of the orders and the keys for their separation are useful not only to the palæontologist but also to the student of recent forms. The author concludes that at an early geological age the Arachnida split into a number of orders ; but that all of them exhibit the same fundamental trends, in. cluding a shortening of the abdomen through a loss of posterior segments. There is also a tendency to simplification, exemplified, inter alia, by the loss of abdominal appendages save the combs in scorpions, and the spinnerets in spiders, and, further, in the former by a reduction of the number of teeth in the comb and in the latter by a reduction of the number of spinnerets from four pairs to one pair. The work concludes with an interesting and useful discussion of these and similar trends, not only in the class as a whole, but also in its various subdivisions, and con. sideration of the evolutionary and classification significance of such trends. The paper is provided with a full bibliography, well indexed, and illustrated by eighty-three plates, thirty of which are excellent photographic reproductions of the material.

\section{Reactions of some Passerine Birds to a Stuffed Cuckoo}

DuRING the strig of 1948 George Edwards, Eric Hosking and suart Smith carried out experiments to test th reactions of certain of the smaller birds to the Apence of a stuffed cuckoo and other animals in their nesting territories (British Birds, 42, No. 1; January 1949). Experiments were of an exploratory nature, but enough evidence has been collected to show that certain birds appear able to determine one type of 
dummy from another. Willow-warblers will attack a stuffed cuckoo but will not go near a stuffed sparrowhawk. Nightingales will attack both hawk and cuckoo, but fear a stuffed stoat. Blackbirds disregard a cuckoo but attack a jay. Tree-pipits attack a cuckoo violently, but will not approach a jay; whin. chats attack both cuckoo and sparrow-hawk. The article contains a detailed account of these reactions as well as many excellent close-up photographs which were taken during the experiments.

26

Mushroom Diseases

A SMALI booklet has recently been compiled by Mr. Fred C. Atkins Jntitled "Major Diseases of the Cultivated Whit Y shroom" (Yaxley, Peterborough : Midlands ynodp Publications, 1948; 2s. 6d.). It deals with bfcterial pit, caused by Pseudomonas (?) fletprescens, bacterial blotch (Phytomonas Tolaasi), cobveb or mildew due to Dactylium dendroides, bubble (Mycogone perniciosa) and brown spot (Verticillium spp.). Most of the descriptions have appeared in the Bulletin of the Mushroom Growers' Association; but practical growers and others will welcome their collection into a booklet with photographs, drawings and succinct accounts of control. It is planned to issue further booklets on major competitors, and on minor diseases and competitors of the cultivated mushrpom.

\section{Unstability in the Rust Fungi}

THe life-history ofy rust fungus is usually regarded as sufficiently solle to have some diagnostic value. Recent nowlefge shows, however, that there are exceptio . Mid colm Wilson (Proc. Roy. Soc. Edin., B, 63, P tt 2, No. 11, 177; 1948) reviews the literture 8 aling with instability, and describes four British cases where uredosori contained a proportion of teleutospores. All the unstable species now known belong to the Pucciniaceæ, a relatively advanced family of the rust fungi. The taxonomic position of their host species also agrees with their relatively advanced condition. The interesting theory that unstable species lead to the production of microPuccinia forms is now formulated, and seems to provide a useful insight into the phylogeny of these organisms. Special environmental conditions appear to induce instability of life-history, and this itself is another interesting feature.

\section{Strains of Host and Virus}

StraIns of various virus diseases are now well recognized by reafa ch workers. B. Kassanis and Ireson W. Nalin (\%. Pomol. Hort. Sci., 23, Nos. 3, 4; Del 19:7) now demonstrate two strains in a ho plant (Uthite Burley tobacco), which are barely dist iguishable morphologically, but react differently to virus infection. Tomato aucuba mosaic produces necrotic local lesions or systemic necrosis in one host strain, and a yellow mottle in the other. Some strains of tobacco mosaic also react necrotically in the firstmentioned host strain. This unsuspected selective action of the host may possibly explain discrepancies in etiology reported by various workers. The behaviour of various strains of potato virus $Y$ has also been studied by F. C. Bawden and B. Kassanis (Ann. Appl. Biol., 34, No. 4, 503-516; Dec. 1947). These various strains cause diseases in the variety Majestic, ranging in severity from mild mosaic to leaf-drop streak. Symptoms of the strains are also compared with the serologically related potato virus
$C$, and possible mechanisms for the evolution of viruses $C$ and $Y$ are discussed.

\section{Science and Society

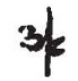

THE Education Ceptres Association is arranging a non-technical co Ase for laymen and men of science who want dopportunity of studying the relations betweemscience and society ; it is to be held at West. harr Halse, Barford, near Leamington, Warwickshire, daring August 20-27. Inquiry will be made into the application of science to the raising of the standard of living and of bodily health; and in considering the reciprocal issues between science and society particular attention will be paid to recent developments in industrial and agricultural practice and to such topical questions as the atomic bomb and the Lysenko controversy. The course will be conducted by lectures and by seminar discussions, and during the latter students will concentrate either on chemical and physical considerations or on biology as applied to nutrition and disease. Further particulars can be obtained from the Education Secretary, Educational Centres Association, 8 Endsleigh Gardens, London, W.C.1.

\section{Announcements}

A CONFERANCE on "The Place of Agriculture in Education will be held at Lord Wandsworth College, Long Satton, near Basingstoke, Hants, on July 20. Thy conference will be opened by the Minister of Agriculture. Further information may be obtained from the bursar of the College, Mir. L. G. Troup.

THE fourteenth Cold Spring Harbor Symposium on Quantitative Biolog will be held during June 8-16. The topic is "Mmino Acids and Proteins", with emphasis on hological aspects of the problem. The meeting wil be international in scope, those taking part coning from Denmark ( $\mathrm{K}$. Linderstrøm-Lang), Frane (C. Fromageot), Great Britain (D. Crowfoot, J. T. Danielli, F. Sanger and R. L. M. Synge), and Sweden (K. O. Pedersen). Attendance is restricted, on account of limitations of space, to about a hundred. The programme and other information can be obtained from the Biological Laboratory, Cold Spring Harbor, New York.

THE Chemical Research Laboratory (Department of Scientificand Industrial Research), at Teddington, Viiddlesel, is again holding a series of 'open days' this yar. There will be three sessions, on June 30 (afternoon), and on July 1 (morning and afternoon). Applications from industrial firms wishing to send representatives should be sent to the Director before June 20; those already on the invitation list need not apply again.

Prof. C K. Ingowd points out that extended series gf Fermi doublets of the kind that Prof. R. K. Asuydi and M. E. Padhye report (Nature, April 23, p 638) in the near ultra-violet emission spectrum of benzene, as well as analogous series in the absorption spectrum, have been fully described and discussed by Dr. F. M. Garforth and himself (J. Chem. Soc., 417, 427 ; 1948).

REFERENCE was made in the leading article of Nature of May 7 to a recently published book "The Unity of European History" (London: Jonathan Cqpo, Ltd., 18s. net), by Mr. John Bowle. We regret that, throughout the article, the author's name was spelled incorrectly. 